\title{
Large unilateral medial rectus recession for the treatment of esotropia
}

\author{
TRUDI R GRIN AND LEONARD B NELSON \\ From the Pediatric Ophthalmology Service of Wills Eye Hospital, Philadelphia, Pennsylvania, USA
}

SUMMARY Sixteen patients with moderate angle esotropia of 30 to 35 prism dioptres were treated with a unilateral medial rectus muscle recession of 6 or $6.5 \mathrm{~mm}$. Thirteen of sixteen patients $(80 \%)$ were straight postoperatively or had 12 prism dioptres or less of esotropia. Three of the 16 had greater than 12 prism dioptres of esotropia, and none were exotropic. This procedure should be considered as an alternative approach in the treatment of moderate angle esotropia.

The recession of a single medial rectus muscle for the treatment of various forms of esotropia has been well described. Chamberlain reported 100 cases of unilateral medial rectus recession of 3.5 to $4 \mathrm{~mm}$ and concluded that it was a feasible operation for minimal non-accommodative esodeviations measuring less than 20 prism dioptres.' A unilateral medial rectus muscle recession of $5 \mathrm{~mm}$ has also been successfully used to treat small angle partially accommodative or residual esotropia. ${ }^{2}$ In addition, high $\mathrm{AC} / \mathrm{A}$ ratio has been treated with 5 and $5.5 \mathrm{~mm}$ single medial rectus muscle recession. ${ }^{34}$

Large $(6$ and $6.5 \mathrm{~mm})$ unilateral medial rectus recession as a treatment for moderate angle esotropia (30 to 35 prism dioptres) has not been previously reported to our knowledge. It is the purpose of this paper to review the results of unilateral large medial rectus recessions for the treatment of moderate angle esotropia.

\section{Subjects and methods}

The records of all patients who underwent $6 \cdot 0$ or $6 \cdot 5$ $\mathrm{mm}$ unilateral medial rectus muscle recession at the Pediatric Ophthalmology Service of Wills Eye Hospital between July 1981 and October 1985 were reviewed. A total of 21 patients, excluding patients with Duane's retraction syndrome, underwent a single medial rectus muscle recession during this period. Sixteen patients met the criteria for inclusion in the study, which were as follows: (1) preoperative esotropia of 30 to 35 prism dioptres; (2) no previous horizontal muscle surgery; (3) full ductions and Correspondence to Lconard B Nelson, MD, Wills Eye Hospital, 9th and Walnut Streets, Philadelphia, PA 19107, USA. versions preoperatively; and (4) follow-up of two months or more. Deviations were measured by the Hirschberg or Krimsky methods in young children or in patients with dense amblyopia. The prism and cover tests were used when possible.

All patients underwent a 6.0 or $6.5 \mathrm{~mm}$ unilateral medial rectus muscle recession. The amount of recession was measured from the posterior aspect of the muscle insertion. The amblyopic eye was operated on in the 12 patients with amblyopia. A $6 \cdot 0$ $\mathrm{mm}$ recession was performed for esotropia of 30 prism dioptres and a $6.5 \mathrm{~mm}$ recession for 35 prism dioptres except for case 11 . In this case a $6.0 \mathrm{~mm}$ recession was performed for a 35 prism dioptre esotropia. Because of the undercorrection it was decided that all subsequent cases of 35 prism dioptre esotropia should undergo a larger recession. Surgery was performed under general or retrobulbar anaesthesia by the Parks cul-de-sac approach. In three patients the surgical procedure was modified to an adjustable suture technique which as been previously described. ${ }^{5}$

Postoperative measurements are those obtained at the most recent follow-up visit. For the purpose of this study an alignment within 12 prism dioptres of straight at the most recent follow-up visit was considered a good result. The majority of patients in this study were amblyopic, and in these patients an alignment within 12 prism dioptres of straight can be considered a cosmetically acceptable postoperative result. Further, in patients with esotropia associated with impaired vision an undercorrection would be desirable because of the tendency for eventual replacement of the esotropia with secondary exotropia. ${ }^{6}$ 


\section{Results}

Sixteen consecutive patients underwent a 6 or $6.5 \mathrm{~mm}$ unilateral medial rectus muscle recession. All patients had a postoperative deviation of 30 to 35 prism dioptres of esotropia, with a mean deviation of 30 prism dioptres (Table 1). Patients ranged in age from 3 to 57 years with an average age of 21.5 years. Follow-up ranged from 2 to 31 months with an average follow-up of 9.3 months. Twelve of 16 patients $(75 \%)$ had decreased vision in the strabismic eye secondary to amblyopia. Three patients underwent a $6 \mathrm{~mm}$ recession by means of an adjustable suture; however, none of these patients required any adjustment. Therefore in these three patients the amount of recession remained at $6 \mathrm{~mm}$.

For a $6 \mathrm{~mm}$ recession (14 patients) the mean postoperative deviation was 6.6 prism dioptres, with a range of 0 to 20 prism dioptres of esotropia. The average amount of correction for a $6 \mathrm{~mm}$ recession was 21 prism dioptres.

Table 1 Summary of clinical status

\begin{tabular}{|c|c|c|c|c|c|c|}
\hline Case & $\begin{array}{l}\text { Age } \\
(y r)\end{array}$ & $V A$ & $\begin{array}{l}\text { Preop. } \\
\text { deviation } \\
(P D)\end{array}$ & $\begin{array}{l}\text { Postop. } \\
\text { deviation } \\
(P D)\end{array}$ & $\begin{array}{l}\text { Medial } \\
\text { rectus } \\
\text { rec. }(\mathrm{mm})\end{array}$ & $\begin{array}{l}\text { Follow- } \\
\text { up } \\
\text { (months) }\end{array}$ \\
\hline 1 & 5 & $\begin{array}{l}O D=20 / 30 \\
O S=20 / 200\end{array}$ & 30 & 0 & 6 & 12 \\
\hline 2 & 21 & $\begin{array}{l}\mathrm{OD}=20 / 20 \\
\mathrm{OS}=20 / 20\end{array}$ & 30 & 0 & 6 & 12 \\
\hline 3 & 11 & $\begin{array}{l}\mathrm{OD}=20 / 20 \\
\mathrm{OS}=20 / 40\end{array}$ & 30 & 0 & 6 & 9 \\
\hline 4 & 3 & $\begin{array}{l}O D=20 / 100 \\
O S=20 / 30\end{array}$ & 30 & 0 & 6 & 5 \\
\hline 5 & 6 & $\begin{array}{l}\mathrm{OD}=20 / 20 \\
\mathrm{OD}=20 / 50\end{array}$ & 30 & 2 & 6 & 3 \\
\hline 6 & 4 & $\begin{array}{c}\mathrm{PD}=20 / 20 \\
\mathrm{OS}=\mathrm{CF} \text { at }\end{array}$ & $\begin{array}{l}30 \\
2 \text { feet }(0 \cdot 6\end{array}$ & $\begin{array}{r}6 \\
m)\end{array}$ & 6 & 9 \\
\hline 7 & 6 & $\begin{array}{l}O D=20 / 200 \\
O S=20 / 20\end{array}$ & 30 & 20 & 6 & 9 \\
\hline 8 & 44 & $\begin{array}{l}\mathrm{OD}=20 / 20 \\
\mathrm{OD}=20 / 200\end{array}$ & 30 & 8 & 6 & 8 \\
\hline 9 & 35 & $\begin{array}{l}O D=20 / 20 \\
O S=20 / 70\end{array}$ & 30 & 12 & 6 & 2 \\
\hline 10 & 36 & $\begin{array}{l}O D=20 / 20 \\
O S=20 / 20\end{array}$ & 30 & 2 & 6 & 3 \\
\hline 11 & 57 & $\begin{array}{l}O D=20 / 20 \\
O S=20 / 20\end{array}$ & 35 & 20 & 6 & 20 \\
\hline 12 & 33 & $\begin{array}{c}\mathrm{OD}=20 / 20 \\
\mathrm{OS}=\mathrm{CF} \text { at }\end{array}$ & $\begin{array}{l}30 \\
3 \text { feet }(0 \cdot 9\end{array}$ & m) & $6 \mathrm{Adj}$. & 31 \\
\hline 13 & 46 & $\begin{array}{l}O D=20 / 20 \\
O S=20 / 20\end{array}$ & 30 & 15 & $6 \mathrm{Adj}$. & 9 \\
\hline 14 & 30 & $\begin{array}{l}O D=20 / 30 \\
O S=20 / 20\end{array}$ & 30 & 4 & $6 \mathrm{Adj}$. & 4 \\
\hline 15 & 4 & $\begin{array}{l}O D=20 / 60 \\
O S=20 / 30\end{array}$ & 35 & 10 & $6 \cdot 5$ & 6 \\
\hline 16 & 3 & $\begin{array}{l}O D=20 / 30 \\
O S=20 / 80\end{array}$ & 35 & 6 & $6 \cdot 5$ & 7 \\
\hline
\end{tabular}

$\mathrm{OD}=$ Right eye $. \mathrm{OS}=$ Left eye $. \mathrm{CF}=$ Counting fingers. $\mathrm{PD}=$ Prism dioptres. VA = Visual acuity. Adj. = Adjustable technique. Rec.$=$ Recession
For a $6.5 \mathrm{~mm}$ recession (two patients) the mean postoperative deviation was 8 prism dioptres, with a range of 6 to 10 prism dioptres of esotropia. The average amount of correction for a $6.5 \mathrm{~mm}$ recession was 27 prism dioptres.

Of the 16 patients treated $13(80 \%)$ were aligned within 12 prism dioptres of straight. Of the remaining patients three were undercorrected. None of the patients were overcorrected. In addition, clinically or cosmetically significant limitation of adduction or lateral incomitance was not noted in any of the patients.

\section{Discussion}

A large recession of a single medial rectus muscle is an effective method of correction for moderate angle esotropia. In this study $75 \%$ of patients had impaired vision in the strabismic eye secondary to amblyopia. In an amblymopic eye with esotropia the standard surgical procedure is a recession of the medial rectus muscle combined with a resection of the lateral rectus muscle. The single medial rectus muscle recession, however, has a number of advantages. A single muscle recession is technically easier than performing a recession and resection in the involved eye. There is less of a tendency toward bleeding in recessions, since the tendon rather than the muscle is severed. The anaesthesia time would be shortened considerably with a single muscle recession. If reoperation for an over- or undercorrection is necessary, the lateral rectus muscle can be recessed in the case of an overcorrection or resected for an undercorrection.

Large bimedial recessions in excess of the traditional $5 \mathrm{~mm}$ have been well described. High rates of success have been reported with large $(6$ and $7 \mathrm{~mm})$ bimedial recessions in patients with large angle congenital esotropia. ${ }^{7-9}$ Critics of large medial rectus recessions have stated that a crippling of adduction may result. Beisner," however, showed through mathematical analysis that a bimedial recession of $8 \mathrm{~mm}$ would result in a loss of only $10 \%$ torque when the eye is adducted $15^{\circ}$. In addition, Mittleman and Folk" have presented clinical evidence that a rerecession of the medial rectus $13.5 \mathrm{~mm}$ from the limbus is a safe and effective procedure. In the 16 patients in this study a significant limitation of adduction was not noted.

A large unilateral medial rectus muscle recession is an effective and safe method of treating moderate angle esotropia. We found the overall correction for a $6 \mathrm{~mm}$ recession to be 21 prism dioptres and for a 6.5 $\mathrm{mm}$ recession 27 prism dioptres.

This work was supported in part by a grant from Fight for Sight Inc., New York, to the Fight for Sight Children's Eyc Center of Wills Eyc Hospital, Philadelphia, Pennsylvania. 


\section{References}

1 Chamberlain $\mathrm{W}$. The single medial rectus operation. J Pediatr Ophthalmol Strabismus 1970; 7: 208-11.

2 Poilard ZF, Manley D. Unilateral medial rectus recession for small angle esotropia. Arch Ophthalmol 1976; 94: 780-1.

3 Mittleman D. The surgical treatment of combined-mechanism accommodative esotropia. In: Reinecke RD, ed. Strabismus II. New York: Grune and Stratton, 1984: 203-10.

4 Zak TA. Preliminary results of treatments of high AC/A with medial rectus recession. In: Reinecke RD, ed. Strabismus II. New York: Grune and Stratton, 1984: 181-7.

5 Nelson LB, Calhoun JH, Harley RD, Freeley DA. Cul-de-sac approach to adjustable strabismus surgery. Arch Ophthalmol 1982; 100: 1305-7.

6 Wheeler MB, Parks MM. Concomitant esodeviations. In: Duane TD, ed. Clinical ophthalmology. Philadelphia: Harper and Row, 1985: 1: chapter 12: 12.
7 Prieto-Diaz J. Large bimedial rectus muscle recession in early esotropia with bilateral limitation of abduction. J Pediatr Ophthalmol Strabismus 1980; 17: 101-5.

8 Hess JB, Calhoun JH. A new rationale for the management of large angle esotropia. J Pediatr Ophthalmol Strabismus 1979; 16: $345-8$.

9 Szmyd SM, Nelson LB, Calhoun JH, Spratt C. Large bimedial rectus recessions in congenital esotropia. $\mathrm{Br} \mathrm{J} \mathrm{Ophthalmol} \mathrm{1985:}$ 69: $271-4$.

10 Beisner DH. Reduction of ocular torque by medial rectus recession. Arch Ophthalmol 1971; 85: 13-7.

11 Mittleman D. Folk ER. The surgical treatment of undercorrected esotropia: an evaluation of the effect of recession of the medial rectus muscle $13.5 \mathrm{~mm}$ from the limbus. Ophthalmology (Rochester) 1975; 19: 738-44.

Accepted for publication 3 July 1986. 